\title{
Letter from the Institute
}

When you receive this issue, the year 1992 has ended and with it the quincentenary of the first voyage of Columbus to America. No doubt, the wave of new publications on the first contact between Europe and the Americas will not come to a sudden end and this issue contains a contribution on the knowledge of Dutch humanists with regard to the New World. In addition, there are articles on the debate on the 'End of History', on the agricultural technology in Moghul India and on the historiography regarding indentured labour in the Dutch East Indies. Special mention should be made of a contribution by one of the editors of this journal, Prof. D.H.A. Kolff, who presents us with a translation of his inaugural lecture delivered upon his appointment to the chair of Modern South Asian History at Leiden University.

Two articles deal with the backbone of European expansion history: archival research. Dr. Kooiman discusses the value of missionary archives and $\mathrm{Dr}$. Van Goor points to the unique information which is contained in the archives of the Dutch East India Company (VOC). In the next issue we will pay special attention to the publication of the new inventory of the VOC-archives, M.A.P. Meilink-Roelofsz, R. Raben and H. Spijkerman (eds.), De archieven van de Vereenigde Oostindische Compagnie, 1602-I795 ('s-Gravenhage, 1992).

One of the editors of this long-awaited inventory, Remco Raben, has also played an important part in editing Itinerario over the past period. First, as a student Remco Raben provided valuable editorial assistance and upon his return to the Institute as a Ph.D. student he became one of the editors. Now he wants to resign in order to have more time available for the completion of his Ph.D. thesis. We are sad to let him go and wish him the very best.

The Editors 